\title{
Pengembangan Kawasan Pinggiran Kota dan Permasalahan Lingkungan di Kampung Seni Nitiprayan, Bantul
}

\author{
Widodo B., ${ }^{1}$ dan R. Lupyanto ${ }^{2}$ \\ ${ }^{1}$ Jurusan Teknik Lingkungan, FTSP, UII \\ ${ }^{1}$ Pusat Studi Perubahan Iklim dan Kebencanaan (PuSPIK), UII \\ ${ }^{2}$ Pusat Studi Lingkungan (PSL), UII \\ email:widodo.bronto@gmail.com
}

\begin{abstract}
Abstrak
Pengembangan wilayah secara umum masih kurang menyentuh dan memperhatikan karakteristik khas daerah rurban (rural-urban). Daerah ini umumnya berada pada pinggiran perkotaan, yang terpengaruh oleh karakter kota (baik fisik maupun non fisik) dan di sisi lain juga masih memiliki karakter desa. Tanpa perhatian yang khusus dalam pengembangannya, wilayah ini akan semakin menerima implikasi problematika kota yang kompleks dan semakin pudar potensi asalnya. Kampung Nitiprayan adalah salah satu pinggiran kota yang mengkhawatirkan perkembangan lingkungan dan pembangunannya. Kawasan ini secara fisiografis terletak pada pinggiran Kota Yogyakarta dan secara administratif masuk dalam Desa Ngestiharjo, Kecamatan Kasihan, Kabupaten Bantul, DIY. Tulisan ini bertujuan merancang arahan dan strategi pengembangan Kampung Nitiprayan yang berorientasi pada pelestarian lingkungan dan optimalisasi potensi unggulan wilayah. Analisis dilakukan dengan metode SWOT berdasarkan data sekunder dan survei lapangan. Nitiprayan sebagai wilayah pinggiran kota memiliki potensi unggulan dalam bidang seni budaya. Nitiprayan diarahkan secara umum sebagai kampung wisata terpadu dan berkelanjutan. Basis pengembangan adalah seni budaya lokal dengan berorientasi pada peningkatan kesejahteraan masyarakat, mempertahankan karakter asli, ramah terhadap kelestarian lingkungan hidup, dan penguatan partisipasi masyarakat.
\end{abstract}

Kata kunci: pinggiran kota, pengembangan, lingkungan, Nitiprayan

\section{Pendahuluan}

Selama ini, masih terjadi ketimpangan pembangunan wilayah antara desa dan kota. Pengembangan wilayah juga kurang menyentuh dan memperhatikan karakteristik yang khas dari daerah rurban (rural-urban). Daerah ini umumnya berada pada pinggiran perkotaan, yang terpengaruh oleh karakter kota (baik fisik maupun non fisik) dan di sisi lain juga masih memiliki karakter desa. Tanpa perhatian yang khusus dalam pengembangannya, wilayah ini akan semakin menerima implikasi problematika kota yang kompleks dan semakin pudar potensi asalnya. Untuk itu, banyaknya potensi di daerah semacam ini perlu dikelola dan dikembangkan dalam orientasi peningkatan kesejahteraan masyarakat dan mewujudkan tata kelola wilayah yang berkelanjutan.

Salah satu wilayah yang termasuk daerah rurban adalah Kawasan Nitiprayan. Kawasan ini secara fisiografis terletak pada pinggiran Kota Yogyakarta (Kawasan Perkotaan Yogyakarta), dan secara administratif termasuk dalam Desa Ngestiharjo Kecamatan Kasihan, Kabupaten Bantul, DIY. Nitiprayan juga masuk dalam Kawasan Perkotaan Yogyakarta (KPY). Implikasi melebarnya permasalahan Kota Yogyakarta ke kampung ini dapat dilihat dalam banyak aspek seperti sifat sosial 
yang cenderung mengarah ke individualis, kenampakan fisik spasial yang terus padat permukiman, permasalahan sampah dan ramainya lalu lintas, dan lainnya. Kondisi ini semakin mengkhawatirkan dengan kesan kurangnya perhatian pemerintah. Nitiprayan sebagai wilayah perbatasan Kota Yogyakarta jauh dari ibu kota Kabupaten Bantul, sehingga kurang terurus pengembangannya. Hal ini membutuhkan arahan dan strategi untuk merancang dan mengawal perkembangan wilayahnya agar tidak terkena implikasi karakter kota dan mempertahankan karakter unggulannya.

\section{Potensi dan Problematika Wilayah}

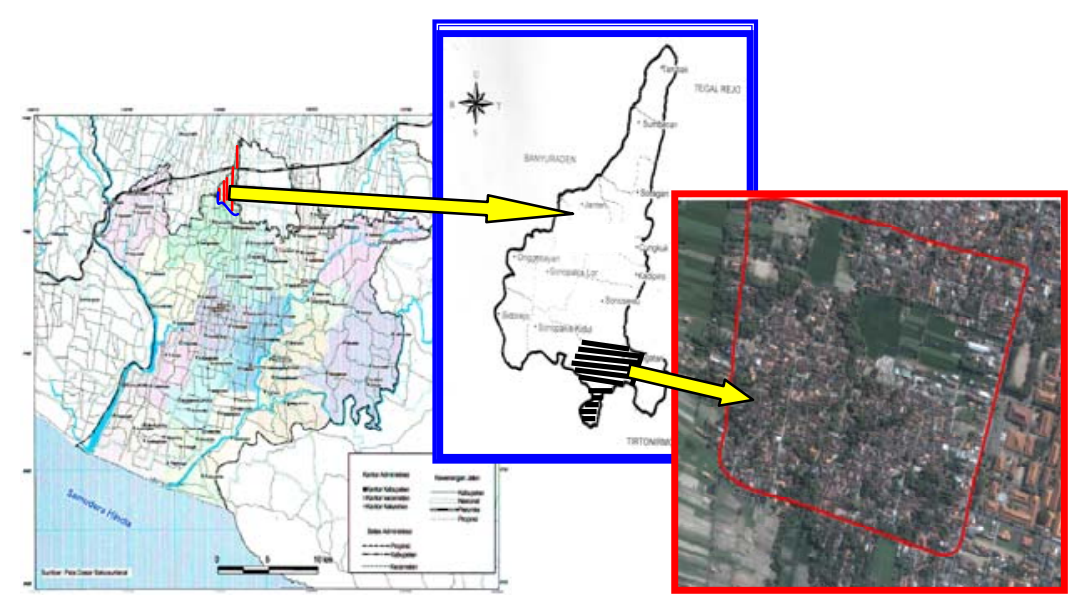

Gambar 1. Peta Lokasi Kawasan Kampung Nitiprayan

Kecamatan Kasihan berdasarkan karakteristik sumberdaya alam dan lokasi geografisnya termasuk dalam Kawasan Aglomerasi Perkotaan. Kawasan ini pada dasarnya merupakan kawasan pertanian yang telah berkembang menjadi Kawasan Perkotaan Yogyakarta. Rencana Pembangunan Jangka Menengah Kabupaten Bantul mengkategorikan Kecamatan Kasihan sebagai daerah suburban yang strategi pembangunannya berupa penataan dan pengembangan area sesuai atau sejalan dengan perkembangan Kota Yogyakarta dengan tetap mempertahankan fungsi sawah irigasi pada sisi luar area suburban. Lahan didalamnya diprioritaskan untuk industri kecil, perdagangan, jasa, dan permukiman. Rencana Tata Ruang Wilayah Kabupaten Bantul Tahun 2006-2016 juga memasukkan Kecamatan Kasihan ke dalam Satuan Wilayah Pengembangan II dimana pembangunan wilayahnya diarahkan untuk pengembangan kawasan permukiman dan pelayanan yang berorientasi perkotaan.

Nitiprayan secara geografis memiliki posisi strategis dan interlinkages dengan lokasi-lokasi lain. Kampung ini terletak tidak jauh dari beberapa kawasan yang berbasis budaya, misalnya Kasongan, Kraton Yogyakarta, tempat seniman Butet Kertarajasa, Kyai Kanjeng, dan Joko Pekik. Nitiprayan dekat dengan kawasan pendidikan, seperti SMKI, ISI, dan UMY. Dengan basis industri juga dekat dengan PT. Madukismo, Sentra kerajinan kulit Manding, dan Sentra Kerajinan Gerabah Kasongan. 
Jumlah penduduk Nitiprayan pada tahun 2007 adalah 2341 jiwa, yang terbagi dalam 543 KK. Jumlah penduduk perempuan sebanyak 1.110 jiwa atau 47,4\% dari total penduduk, sedangkan yang berjenis kelamin laki-laki sebanyak 1.231 jiwa atau sebesar 52,6\% dari total penduduk yang ada.

Karakteristik kehidupan masyarakat masih diwarnai kehidupan khas pedesaan. Hal tersebut tampak dari ikatan sosial antar warga yang masih kuat. Nilai keramahtamahan, gotong royong, dan persaudaraan masih teraplikasikan dalam kehidupan sehari-hari masyarakatnya. Sebagian besar penduduk juga masih memegang teguh tradisi yang ditinggalkan tetua mereka, meskipun ada beberapa yang hilang seiring masuknya pengaruh kehidupan kota yang letaknya tidak terlalu jauh dari wilayah tempat tinggal mereka. Tradisi yang masih kerap mereka laksanakan misalnya Suran (upacara/ritual yang dilakukan pada I malam satu sura) dan Nyadran (biasa disebut 'apem-an', dilakukan ketika ruwatan sebelum masuk Bulan Ramadhan). Sedangkan tradisi yang sekarang sudah jarang dilaksanakan misalnya mengadakan Kenduri.

Di Nitiprayan terdapat kegiatan seni budaya yang melibatkan banyak warga, khususnya kelompok warga usia dewasa. Warga yang berminat dalam seni musik telah mengembangkan beberapa kelompok musik khususnya keroncong, kesenian tradisional Gejog Lesung, Rewe-rewe, dan seni lukis yang sudah merambah tidak hanya di kominitas lokal, tetapi juga sampai event di tingkat nasional bahkan internasional. Di kawasan ini juga terdapat satu kelompok seni wayang kulit. Banyak seniman yang berasal dan tinggal di kampung ini. Seniman-seniman tersebut diantaranya adalah Ong (desain grafis dan koreografer), Putu, Made Sukadana dan Entang Triwarsa (pelukis mahal), Wani (sutradara film dan Butet monolog), Siswanto (Oxygen Band), Ngabdul (ketoprak), Toto (kurator lukisan), Sawung Jabo (musik), Lies Agus (koreografer tari), Dadang (perupa-1001 patung Ancol), dan lain-lain.

Setiap tahun pada Bulan September, warga Pedukuhan Jomegatan menggelar event pagelaran seni besar, yaitu Kenduri Desa. Ini adalah bukti betapa masyarakat sangat menghargai seni yang mereka miliki dan kuasai serta berupaya mengoptimalkan potensi ini. Apresiasi dan partisipasi masyarakat sangat besar, bukan hanya dari warga pedukuhan dan sekitarnya, namun sampai wisatawan nusantara dan luar negeri banyak yang menyaksikan. Mereka sampai menyempatkan diri untuk menginap beberapa hari di pedukuhan ini. Promosi untuk acara event tersebut juga telah didukung oleh Pemerintah Daerah Kabupaten Bantul melalui Dinas Pariwisata-nya dan Pemerintah Propinsi DIY.

Kegiatan ekonomi masyarakat dusun Nitiprayan tergambar dari jumlah penduduk yang menjalankan profesi/mata pencaharian, dimana terdapat keseimbangan antar jenis profesi, khususnya sebagai pegawai negeri, karyawan swasta, TNI, wiraswasta, dan pertanian (Gambar 2). 
Meskipun Kawasan Nitiprayan secara geografis relatif dekat dengan perkotaan, namun penduduk dusun ini yang bergerak pada sektor pertanian jumlahnya cukup banyak, yaitu 79 orang dan sebanyak 182 orang statusnya sebagai buruh tani. Sementara itu, penduduk yang bekerja sebagai PNS sebanyak 95 orang, TNI sebanyak 3 orang, dan karyawan swasta sebanyak 98 orang. Selain sebagai karyawan, tidak sedikit jumlah penduduk yang berusaha secara mandiri/wiraswasta, khususnya sebagai seniman, pengrajin barang seni, warung makan, dan usaha perdagangan, yaitu sekitar 80 orang, pengrajin batu merah sebanyak 12 orang, pengrajin kapur sebanyak 1 orang, dan tukang (bangunan/kayu) sebanyak 98 orang, jasa (dukun bayi) sebanyak 1 orang, sedangkan penduduk yang berstatus pensiunan ada sebanyak 24 orang.

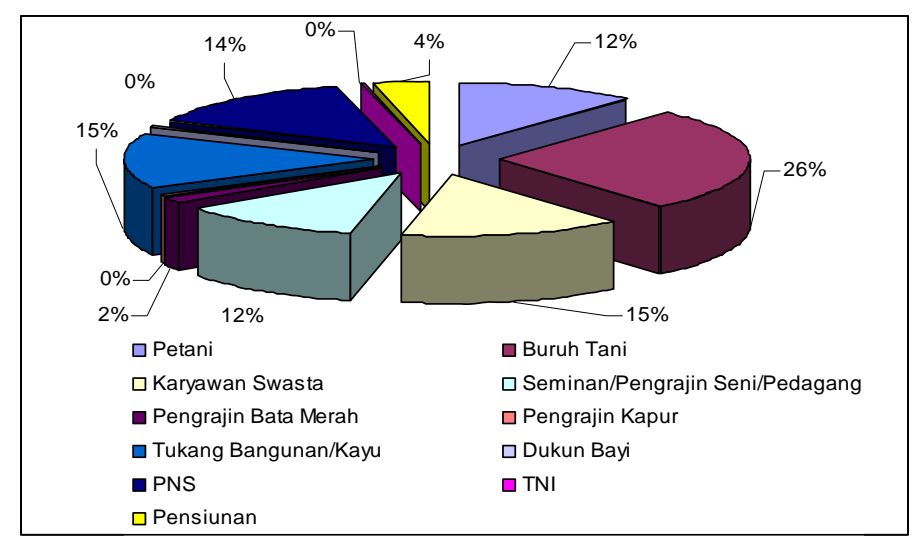

Gambar 2. Persentase Jumlah Penduduk Menurut Mata Pencaharian Tahun 2007

Selain menekuni kegiatan mata pencaharian utama, penduduk juga melakukan kegiatan ekonomi produktif, khususnya kegiatan usaha peternakan. Pada tahun 2007, tercatat berbagai jenis hewan ternak yang dipelihara warga dengan rincian sebagai berikut: 1.012 ekor ayam kampung, 72 ekor itik, 59 ekor kambing, 2 ekor sapi perah, 35 ekor sapi biasa, dan sebanyak 1 ekor kuda. Kegiatan peternakan yang dikembangkan di dusun ini lebih diorientasikan sebagai kegiatan penunjang, khususnya dilakukan oleh penduduk yang berprofesi sebagai petani/buruh tani.

Sarana pendukung kegiatan ekonomi masyarakat, selain terdapat beberapa sarana perdagangan, termasuk galeri seni, juga terdapat 4 koperasi simpan pinjam. Koperasi ini berorientasi pada upaya pemenuhan kebutuhan keuangan warga, baik untuk simpanan maupun kredit konsumsi dan usaha dalam skala yang relative kecil. Meskipun skala usaha dari koperasi simpan pinjam yang ada di daerah ini masih relatif kecil, namun keberadaan jasa keuangan mikro ini sangat membantu warga dalam hal pemenuhan kebutuhan-kebutuhan keuangan.

Belum terdapat penginapan atau hotel di Nitiprayan, karena pada hari-hari biasa jarang ada wisatawan yang berkunjung. Namun jika dibutuhkan, misalnya pada event besar seperti Kenduri Desa setiap Bulan September, wisatawan dapat memanfaatkan rumah-rumah yang dikontrakkan 
atau kamar di rumah penduduk untuk menginap (home stay). Sawah yang menghampar memiliki pemandangan yang indah dan potensial sebagai daya tarik wisata. Sarana wisata sebagian besar adalah untuk minat khusus yaitu seni budaya. Beberapa sarana tersebut berbentuk gallery-gallery seni. Seperti gallery lukis Putu (Gambar 3a), gallery Sawong Jabo (Gambar 3b) dan gallery Ong (Gambar 3c). Untuk wisata budaya, selain ada beberapa galeri yang cukup besar, juga home industries serta atraksi seni budaya yang beragam. Terdapat satu toko/showroom kerajinan.
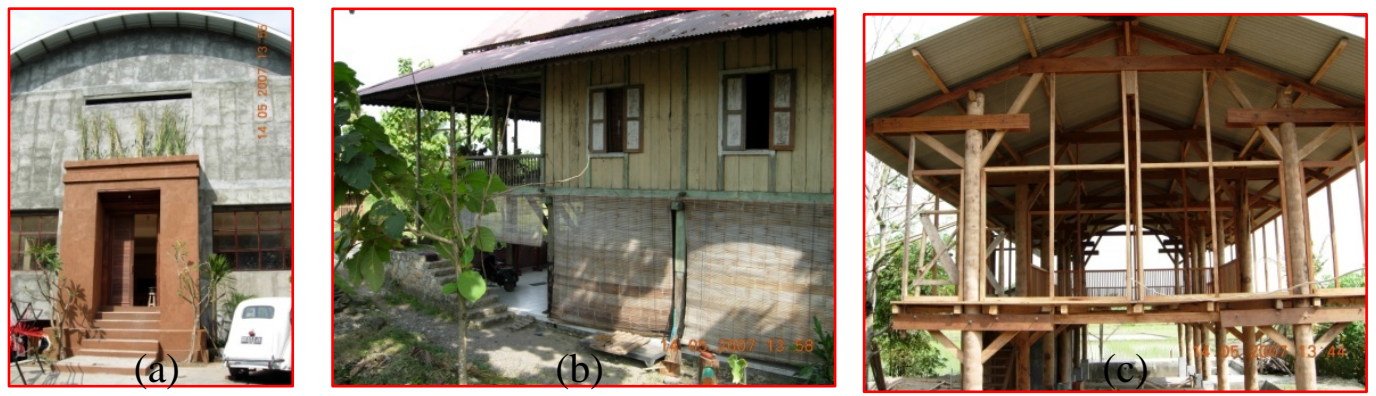

Gambar 3. Gallery Seni di Nitiprayan: gallery lukis Putu (a); gallery Sawong Jabo (b); gallery Ong (c)

Kondisi sosial budaya dan ekonomi masyarakat Nitiprayan di atas telah memberikan potensi sebagai berikut:

a. Kemauan dan kesanggupan yang tinggi dari masyarakat dalam pengembangan kawasan

b. Sikap dan kegiatan gotong-royong menjadi salah satu sifat dasar masyarakat yang masih terjaga

c. Adat istiadat dan kearifan lokal masih dijunjung tinggi oleh sebagian besar masyarakat

d. Telah terbentuk berbagai kelompok komunitas/kegiatan

e. Kawasan Nitiprayan sudah dikenal sebagai "kampoeng seni" oleh masyarakat luas, bahkan wisatawan mancanegara

f. Banyaknya penduduk usia produktif yang menekuni bidang seni dan budaya

g. Telah berkembangnya sektor riil ekonomi rakyat yang variatif.

Permasalahan sosial budaya dan ekonomi di Nitiprayan antara lain:

a. Berbagai organisasi masyarakat, termasuk kelompok seni dan budaya belum dimanfaatkan secara optimal oleh anggota masyarakat

b. Manajemen kelembagaan dari kelompok-kelompok yang ada belum tertata professional

c. Kurangnya pembinaan secara formal pada generasi muda dalam mengembangkan seni budaya lokal dan meningkatkan kreasi dan inovasi produktivitas ekonomi 
d. Sifat masyarakat yang saling menunggu dan membutuhkan komparasi riil dengan keberhasilan daerah lain

e. Berbagai usaha produktif, baik sektor ekonomi riil maupun seni budaya masih bersifat individual dan belum terkemas sistematis dalam pengelolaannya

f. Berbagai potensi belum dipromosikan secara efektif dan masih bersifat personal

g. Angka kemiskinan masih relatif tinggi dan tingkat pendidikan rendah juga relatif besar

Sebagian besar lahan di Nitiprayan digunakan untuk permukiman. Kegiatan jasa dan komersial banyak tersebar di Jalan Bugisan (perbatasan pedukuhan dengan Kota Yogya) dan Jalan Madumurti (jalan masuk ke pedukuhan). Lahan yang digunakan untuk kegiatan pertaniannya (sawah) tersisa seluas 3,83 Ha. Selain itu, yang digunakan untuk pekarangan, yakni sekitar 241,2 Ha. Sebagian besar lahan difungsikan untuk permukiman yaitu 395,77 Ha. Kepadatan penduduk kasar tercatat cukup padat yaitu sekitar 365 orang $/ \mathrm{km}^{2}$, sedangkan kedapatan lingkungan permukiman adalah 137 rumah $/ \mathrm{km}^{2}$. Tata guna lahan pada dasarnya membentuk struktur ruang yang kompak, artinya peruntukan-peruntukan sejenis sifatnya terkonsentrasi pada space tertentu.

Seiring dengan perkembangan dan desakan spasial Perkotaan Yogyakarta, dalam dekade terakhir rumah baru yang terbentuk dan mengalihfungsikan lahan sawah cukup pesat perkembangannya. Misalnya Perumahan Ngesti Elok Gemilang dan Perumahan Tirta Nirmala yang tidak jauh dari jalan masuk ke Nitiprayan. Keduanya dibangun di atas lahan yang sebelumnya merupakan lahan persawahan. Banyak lahan kosong yang belum jelas digunakan untuk apa, meskipun luasannya relatif sempit. Ada yang hijau terisi pepohonan, maupun hanya lahan kering, namun sebagian besar merupakan lahan tidur (non produktif). Selain dari sebaran lahan-lahan kosong tersebut, ruang terbuka hijau yang masih ada juga terdapat pada kompleks pemakaman. Di sekitar rumah warga masih berkeliaran binatang-binatang seperti anjing, unggas, dan sebagainya. Jika tidak dibersihkan, kotoran dari binatang-binatang tersebut bisa menyebabkan penyakit.

Berdasarkan kondisi eksisting di atas, dapat diidentifikasi beberapa potensi dalam aspek tata ruang dan permukiman di Nitiprayan, yaitu:

1. Menempati areal yang cukup representatif sebagai kawasan pedesaan dengan luas sekitar 640,8 hektar serta aset yang ada seperti galeri-galeri kerajinan seperti galeri lukisan, patung; rumah makan.

2. Memiliki homogenitas karakter fisik yang mendukung, yaitu permukiman dengan dukungan fungsi lain yang variatif, seperti lahan pertanian, aktivitas ekonomi rakyat, lokasi kuliner, galeri seni, dan lainnya. 
3. Berada di jalur utama wisata sebagai andalan daerah, yaitu dari Kota Yogyakarta menuju ke kawasan lain di Kabupaten Bantul maupun sebaliknya.

4. Akses transportasi mudah dijangkau dengan fasilitas memadai.

5. Masih memiliki areal ruang terbuka yang tersebar, baik lahan pekarangan maupun lahan pertanian dan bero. Lahan ini dapat difungsikan sebagai daerah recharge maupun konservasi penghijauan serta dapat dioptimalkan untuk fasilitas publik, seperti taman desa, pasar rakyat, atau lainnya. Berdasar survey, pekarangan sekarang banyak ditanami tanaman buah-buhan (45\%), bunga-bungaan (39\%), tanaman keras (3\%), dan lainnya (4\%). Untuk pekarangan menjadi potensi besar bagi pemanfaatan untuk usaha produktif. Pengembangan ruang publik berpotensi diimplementasikan segera, karena sebagain besar lahan ini adalah milik kas desa, sehingga land acquisition-nya lebih mudah.

6. Memiliki potensi alam pedesaan yang masih memungkinkan untuk dipertahankan dan ditingkatkan, seperti areal sawah dengan segala aktivitasnya, kandang peternakan, perikanan, keasrian lingkungan di beberapa titik, keberadaan sungai, dan lainnya.

7. Memiliki fasilitas yang berpotensi dijadikan aspek khas atau unggulan kawasan, seperti gallery seni dan warung kuliner yang murah dan bervariasi menunya.

8. Seluruh permukiman masyarakat terbangun pada lahan yang sah. Hal ini memberikan kesempatan lebih mudah jika akan diterapkan kebijakan/kesepakatan dalam hal penataan aspek permukiman, baik kualitatif maupun kuantitatif.

Beberapa permasalahan atau kekurangan yang terdapat di kawasan ini dalam aspek tata ruang dan permukiman dapat dijabarkan sebagai berikut:

1. Kondisinya mulai terjadi kerusakan, terutama pada Jalan Madumurti yang merupakan akses masuk menuju kawasan ini dari Jalan Raya Bugisan. Kondisi ini belum ditambah dengan kurang ramahnya jalan karena terlalu banyak ‘polisi tidur’ di daerah jalan padat permukiman.

2. Moda angkutan umum ke Nitiprayan mengandalkan bus kota yang hanya melewati Jalan Bugisan dan Ring Road Selatan. Sebagian besar penduduk menggunakan kendaraan pribadi untuk mobilitas sehari- hari. Implikasinya, terjadi peningkatan penggunaan kendaraan, selain kepadatan, polusi udara juga mengkhawatirkan.

3. Banyak lahan pertanian atau sawah yang telah beralih fungsi ke non pertanian terutama untuk pembangunan perumahan.

4. Belum tersedia ruang terbuka untuk dapat digunakan bagi kepentingan publik setempat, baik untuk rekreasi, bermain anak-anak, atau lainnya. Kalaupun ada masih terkesan kurang tertata baik dan belum ada fasilitas-fasilitasnya. 
5. Belum ada karakter permukiman yang mencirikan kekhasan, apalagi secara seni budaya. Rumah-rumah tradisional tinggal beberapa saja dan kondisinya cenderung kurang terawat dan berpotensi beralih ke gaya modern. Rumah baru juga hampir semua sudah tidak menggunakan arsitektural tradisional atau ciri khas tertentu.

6. Kondisinya warung-warung makan kurang menarik dan kurang terjaga kesehatannya. Lingkungan warung terlihat kumuh dan belum diantisipasi terhadap polusi kendaraan membuat daya tariknya kurang, sehingga daya jangkau konsumennya rata-rata masih bersifat lokal.

Jaringan Drainase yang ada di Nitiprayan, pola jaringannya membentuk jaring-jaring paralel dengan memanfaatkan Sungai Widuri sebagai outlet-nya. Saluran drainase mengikuti pola jalan untuk langsung di alirkan ke outlet-nya. Tetapi untuk ruas-ruas yang berdekatan langsung dengan Sungai Widuri pola jaringan drainasenya berbentuk siku dan memotong jalan menuju outlet-nya. Saluran drainase yang berada pada gang atau jalan kecil umumnya merupakan saluran tertutup (Gambar 4a), sedangkan untuk saluran yang berada di jalan yang sudah di aspal umumnya adalah saluran terbuka (Gambar 4b), namun belum optimal dan belum semua ada.
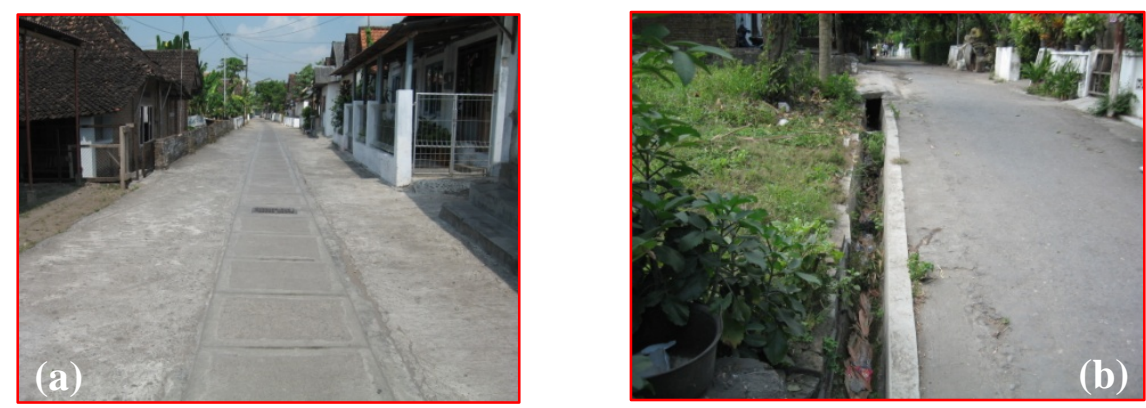

Gambar 4. Saluran Drainase di Nitiprayan: Sistem Tertutup (a); Sistem Terbuka (b)

Air bersih yang dipakai penduduk sebagian besar adalah air dari sumur galian dan sebagian kecil yang lain menggunakan air dari PDAM. Sebagian besar setiap rumah tangga mempunyai sumur masing-masing dengan rata- rata kedalaman lebih dari $10 \mathrm{~m}$. Air diambil langsung dari sumur dengan menggunakan ember (Gambar 5a), ada juga yang ditampung dulu di tempat penampungan sementara (Gambar 5b). Kualitas air bersih, khususnya untuk sumur-sumur yang berada dekat Sungai Widuri memiliki potensi teresapi air sungai.
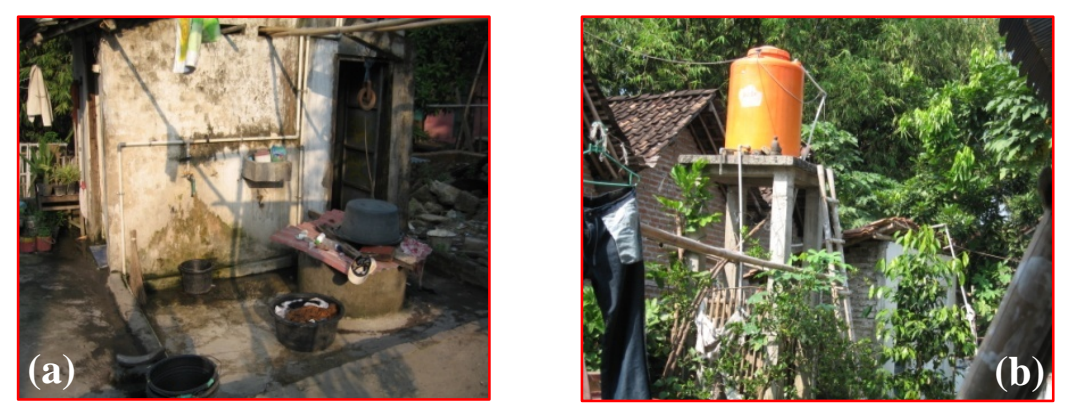

Gambar 4. Kondisi Sumur Gali Penduduk: Sistem Pengambilan Langsung (a); Sistem Penampungan Sementara (b) 
Sampah masih menjadi masalah yang komplek di kawasan Nitiprayan. Sebagian besar penduduk masih membuang sampah di pekarangan mereka sendiri dengan galian timbun atau bakar (Gambar 5a). Beberapa juga hanya dibuang di pekarangan lalu dibakar (Gambar 5b). Ada juga yang membuang sampah di Sungai Widuri (Gambar 5c), yang menyebabkan sungai tersebut tercemar dan tidak dapat berfungsi lagi sesuai peruntukkannya. Sebagian lagi melalui keranjang sampah tiap rumah untuk dikelola dengan Tempat Pembuangan Sementara (TPS) (Gambar 5d). Pengelolaan dilakukan dengan sistem kolektif maupun mandiri. Sistem kolektif yaitu dengan memberikan insentif kepada petugas setempat untuk mengambil dari setiap rumah ke TPS (Gambar 6a). Sistem mandiri dengan membuang sendiri ke TPS, dan insentif dilakukan hanya di TPS dengan "kotak sukarela” (Gambar 6b).

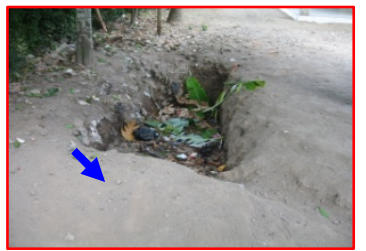

(a)

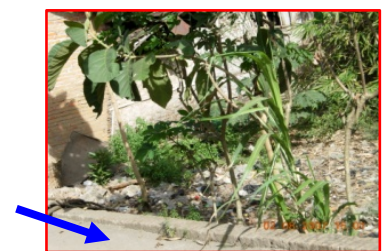

(b)

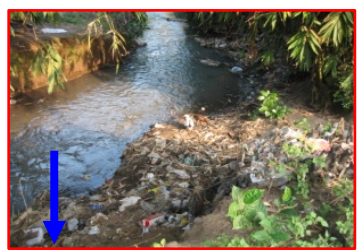

(c)

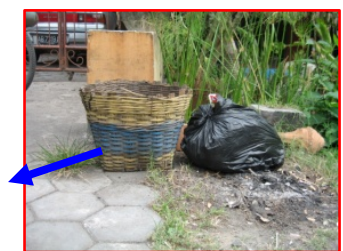

(d)

Gambar 5. Mekanisme Pembuangan Sampah Masyarakat: sistem gali (a); di bakar pada permukaan lahan (b); dibuang ke sungai (c); keranjang sampah per rumah (d)

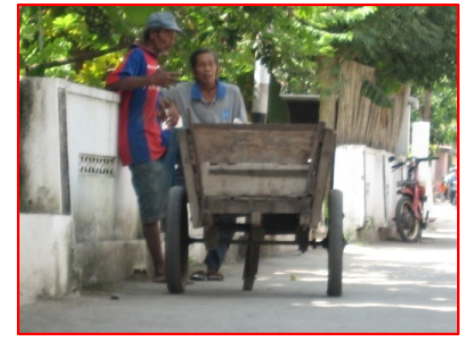

(a)

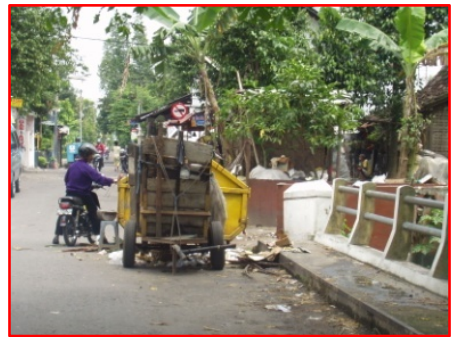

(b)

Gambar 6. Mekanisme Pembuangan Sampah Sistem TPS: kolektif (a); mandiri (b)

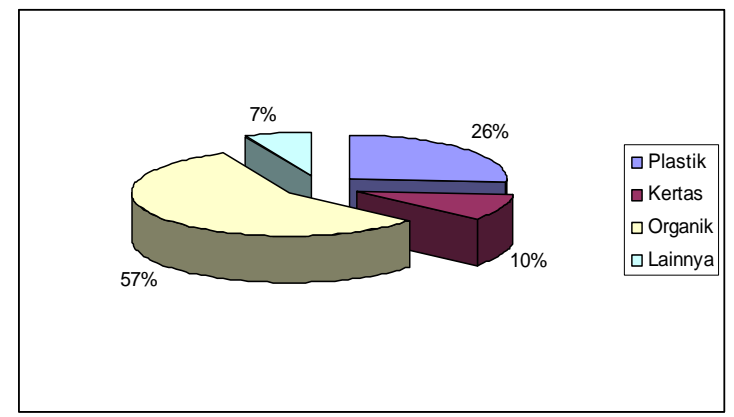

Gambar 7. Jenis Sampah Rumah Tangga di Nitiprayan

Berdasarkan survei lapangan pada 100 responden dapat diidentifikasi berbagai potensi dan permasalahan dalam aspek persampahan tersebut. Dari timbulan sampah yang dihasilkan, paling banyak berbentuk sampah organik (57\%), disusul jenis plastik (26\%), kertas (10\%), dan jenis lainnya (7\%) (Gambar 7). Variasi ini merupakan potensi jika dilakukan pengelolaan secara baik. 
Keberadaan sampah organik akan dapat mendukung sektor pertanian di kawasan ini. Hanya ada seorang warga di RT 8 yang telah memanfaatkan sampah-sampah organik yang dikelola menjadi kompos.

Sebagian besar sampah di Nitiprayan dibuang pada setiap pekarangan dengan sistem cubluk kemudian dibakar. Sebagian lagi sudah dikelola dengan baik yaitu setiap 2 hari diambil petugas setempat untuk di buang di TPS di Bugisan, dengan biaya Rp 5.000,-/bulan. Dan sebagian lain langsung membuang ke TPS. 47\% rumah tangga membuang dengan sistem cubluk, diikuti dengan keranjang sampah-TPS (39\%), dengan cara lain (8\%) dan ke sungai (6\%) (Gambar 8). Dalam pembuangan sampah tersebut sebagian besar belum melakukan pemilahan dari rumah (Gambar 9), hanya ada 19\% yang melakukannya dan kurang ada artinya karena tidak ada perlakuan selanjutnya setelah pemilahan.

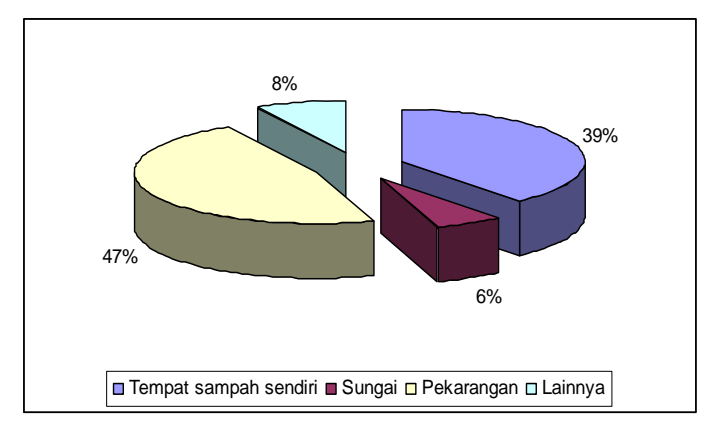

Gambar 8. Implementasi Pemilahan Jenis Sampah

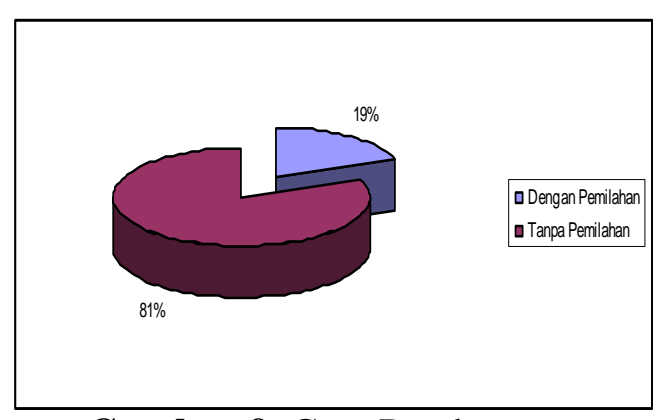

Gambar 9. Cara Pembuangan Sampah

Meskipun beberapa permasalahan muncul dari kondisi di atas, namun terdapat beberapa potensi untuk membuka peluang dilakukannya pengelolaan yang lebih baik. Dalam survey lapangan, didapatkan data bahwa sebenarnya 88\% masyarakat telah mengatahui bahwa sampah bisa dimanfaatkan dan sisanya 12\% yang belum mengetahui. Dalam hal kemauan (willingness), semua yang mengetahui pemanfaatan tersebut bersedia jika akan dilakukan pengolahan, yakni 89\%. Artinya, 1\% yang belum mengetahi pun bersedia. Hal ini merupakan modal besar dalam upaya pengelolaan persampahan selanjutnya, tentunya dengan diikuti sosialisasi dan pemberdayaan yang intensif.

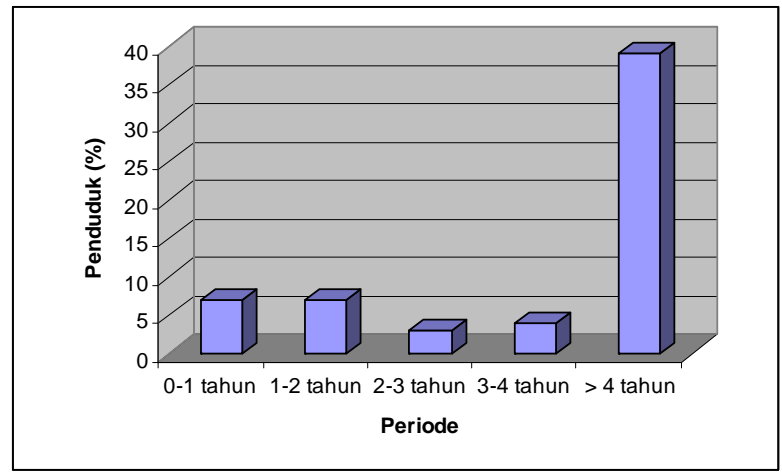

Gambar 10. Periode Masyarakat Memperdalam Sumur 
Sebagian besar air bersih penduduk terlayani melalui sumur gali pribadi dan sedikit di batas kota yang terlayani PDAM. Hasil survey mencatat 90\% warga mendapatkan air bersih dari sumur gali dan hanya 1\% dari PDAM. Dalam hal kuantitas, ketersediaan airtanah di Nitiprayan masih mencukupi, karena secara hidrogelogis berada pada wilayah potensial airtanah, yaitu Basin Yogyakarta. Terbukti, 68\% sumur penduduk memiliki kedalaman 6-10 meter, tidak ada yang $<2$ meter, sedangakn untuk 2-6 meter sebanyak 10\%, dan 22\% untuk yang $>10$ meter. Namun dilihat secara makro dalam katannya dengan wilayah lain, terutama daerah hulu, kondisi ini mulai terjadi gejala yang mengkhawatirkan. Sebagaimana dilaporkan oleh berbagai pihak, konversi lahan di daerah hulu meningkat pesat dan perkembangan kota pun semakin melebar secara spasial. Implikasinya pengambilan airtanah pun akan meningkat dan di bagian hilir (termasuk Nitiprayan) terancam menurun kuantitasnya. Terdapat 68\% sumur yang tetap mencukupi volume kedalamannya dan 32\% yang sering mengalami kekeringan. Meskipun demikian, kondisi ini menunjukkan mulai terjadinya gejala kekeringan sumur saat kemarau. Dari Sungai Widuri pun indikasi ini muncul, 80\% penduduk berpendapat jika Sungai Widuri mengalami kekeringan saat kemarau dan sisanya 20\% menyatakan tetap/stabil debitnya. Guna terus menjamin ketersediaan air tanah ini, seluruh penduduk yang disurvey selalu melakukan perdalaman sumur, meskipun secara periodik masih tergolong lama. Gambar 6.5 menunjukkan 7\% penduduk memperdalam sumur setiap $<1$ tahun, 7\% juga dalam setiap 1-2 tahun, 3\% melakukannya setiap 2-3 tahun, 4\% setiap 3-4 tahun dan paling banyak 39\% melakukan > 4 tahun sekali.

Limbah mayoritas yang dihasilkan adalah limbah domestik dan di buang ke septic tank, sumur resapan dan langsung ke sungai. Berdasarkan survey lapangan, kebanyakan warga membuang limbah rumah tangga yaitu air sisa mencuci pakaian/perabotan dapur ke sungai (38\%) berikutnya 34\% ke septic tank, 10\% ke sumur resapan, dan 12\% ke tempat lain (seperti galian di pekarangan). Selain limbah dapur, limbah domestik juga berupa kotoran manusia. Dalam hal ini sebagain besar penduduk sudah memiliki jamban (WC) sendiri. Tabel 1 menunjukkan 94\% yang memiliki jamban sendiri di rumahnya dan hanya 6\% yang tidak memiliki, dimana mereka ikut dengan tetangganya.

Tabel 1. Kepemilikan Jamban Keluarga di Nitiprayan

\begin{tabular}{|c|c|c|}
\hline Kepemilikan Jamban & Jumlah & $\%$ \\
\hline Ya & 94 & 94 \\
\hline Tidak & 6 & 1 \\
\hline
\end{tabular}

Sumber: Survey Lapangan (2010)

Dari kepemilikkan jamban tersebut 88\% sudah memiliki septic tank dan resapannya, sedangkan 12\% belum memiliki. Secara kualitatif keberadaan septic tank jamban sangat mempengaruhi kualitas air sumur dalam parameter bakteri Colli. Pengaruh ini tergantung pada jarak antara sumur 
dengan septictank. Dalam kondisi fisik/tanah yang normal, di Yogyakarta batas ideal septictank dan sumur sekitar 8-10 meter. Namun, berdasarkan survey terjadi kondisi yang mengkhawatirkan. Gambar 11. menunjukkan 45\% penduduk yang memilki septictank berjarak 6-8 meter. Meskipun paling banyak masih berjarak di atas 8 meter. Namun, seiring dengan perkembangan permukiman kondisi ini tetap mengkhawatirkan.

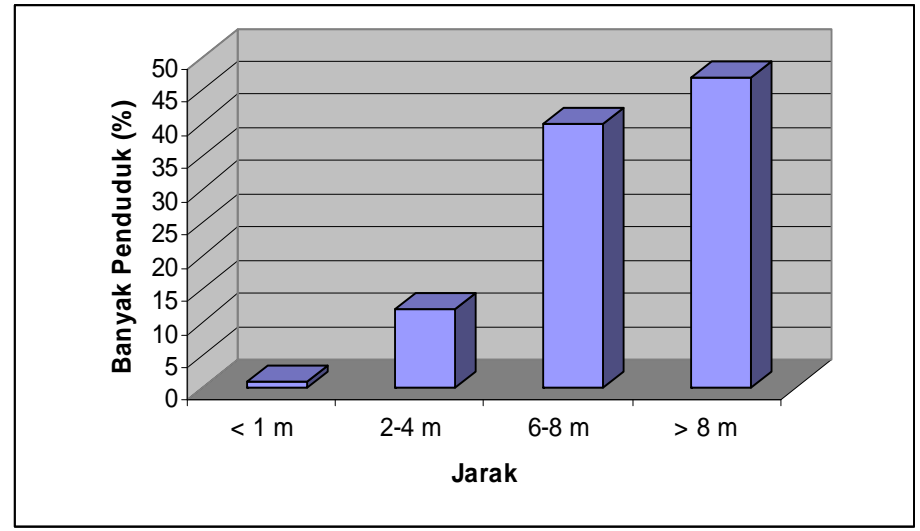

Gambar 11. Jarak Septictank dengan Sumur Milik Masyarakat

Sebagian besar warga sudah sadar akan pencemaran limbah rumah tangga dan mengalirkan air buangan/limbah domestik ke septic tank dan sumur resapan, tetapi warga yang tinggal di pinggiran sungai masih memiliki budaya membuang sampah dan limbah domestiknya ke sungai. Berdasarkan survey, 84\% masyarakat berpersepsi bahwa Sungai Widuri telah tercemar dan kualitasnya lebih buruk daripada kondisi 10 tahun yang lalu. Dari pengamatan langsung juga sangat jelas terlihat kualitasnya. Bau airnya sangat menyengat dengan warna hitam dan banyaknya sampah yang mengalir. Padahal sungai ini memiliki potensi bear dalam mendukung pengembangan kawasan. Selain secara alamiah dapat dijadikan aset panorama. Selain itu juga bisa dimanfaatkan sebagi sumber ekonomi, seperti perikanan. Kondisi sekarang, meskipun tercemar di Sungai Widuri masih bermanfaat bagi penggemar memancing dengan tersedianya cacing sebagai umpan. Usaha ini tentunya akan lebih produktif jika sungainya bersih dan bahkan bisa dijadikan sumber supply bagi usaha pemancingan (Widodo, 2008).

Beberapa RT di Nitiprayan sudah terdapat sumur resapan air hujan, tetapi masih sangat terbatas. Tercatat baru terdapat 5 sumur resapan yang tersebar di titik yang berjauhan. Semuanya masih merupakan resapan pada badan jalan. Dan, kondisi di beberapa lokasi cenderung kurang terpelihara. Sedangkan, untuk skala rumah tangga jauh lebih terbatas lagi. Berdasarkan survey, baru 25\% rumah yang memiiki sumur resapan. Fungsinya pun sebagian besar masih berupa sumur pembuangan limbah rumah tangga, belum sepenuhnya untuk resapan air hujan. 


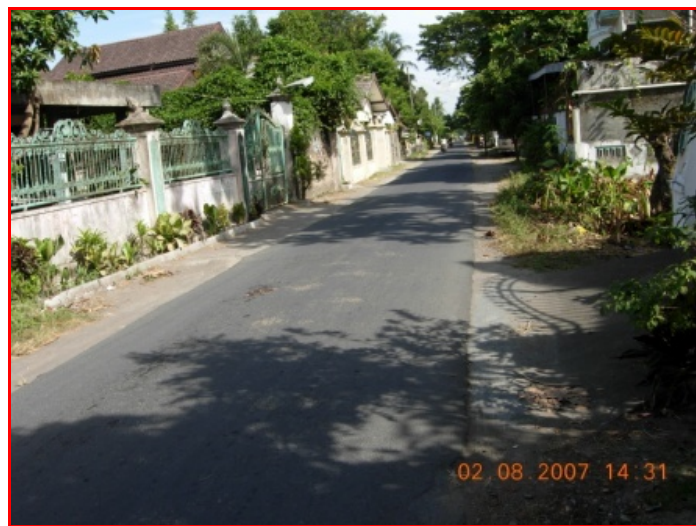

Gambar 12. Ruas jalan utama yang belum dilengkapi drainase

Jaringan drainase memiliki sistem pola mengikuti alur jalan. sebagaimana diuraiakan pada bab 4 untuk jalan utama menggunakan drainase terbuka, seadangkan untuk jalan kampung sifatnya tertutup. Tapi belum semuanya ruas memilikinya. Pada beberapa ruas jalan utama tidak terdapat saluran drainase (Gambar 12), demikian pula pada jalan kampung. Drainase dalam permukiman juga sebagian besar dijadikan sebagai saluran pembuangan limbah rumah tangga. Padahal, outlet drainase semua ke Sungai Widuri. Dengan demikian, turut memberikan andil bagi pencemaran sungai. Drainase yang ada juga belum menggunakan konsep ramah lingkungan. Kecuali pada 5 titik sebagaimana disebutkan di atas, sebagian besar masih langsung dibuang ke outlet (sungai). Ditambah lagi dengan peningkatan kepadatan bangunan dan menurunnya lahan terbuka yang akan meningkatkan surface run off. Akibatnya, selain potensi banjir mengancam (Gambar 13), meskipun skalanya kecil, kuantitas airtanah lokal juga belum mendapatkan kontribusi banyak dengan memanfaatkan air hujan.
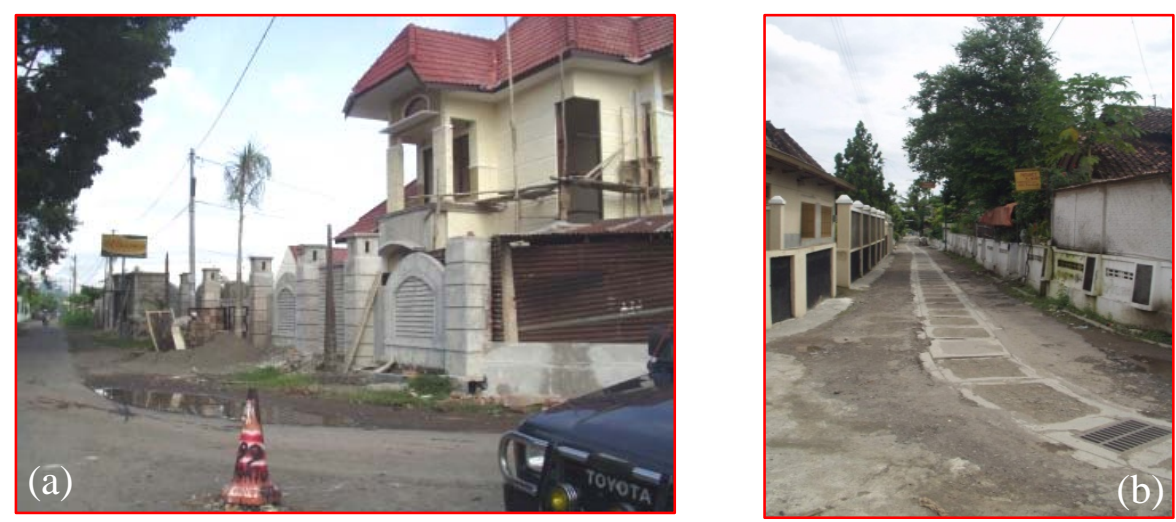

Gambar 13. Kondisi potensin banjir di Nitiprayan: genangan pada ruas jalan (a); ruas jalan rusak akibat limpasan air hujan (b)

Sistem drainase yang ada masih berpegang pada fungsi yang standar diantaranya: (1) mengalirkan air hujan/air secepat mungkin keluar dari permukaan jalan dan selanjutnya dialirkan lewat saluran samping; menuju saluran pembuang akhir; (2) mencegah aliran air yang berasal dari daerah 
pengaliran disekitar jalan masuk ke daerah perkerasan jalan; (3) mencegah kerusakan lingkungan di sekitar jalan akibat aliran air. Tetapi ironisnya prinsip inipun tidak didukung oleh dimensi bangunan drainase yang cukup. Banyak drainase yang dibangun terlalu kecil untuk debit runoff yang terus meningkat. Belum lagi masalah konvensional sampah yang menyumbat saluran sehingga aliran menjadi meluap ke badan jalan.

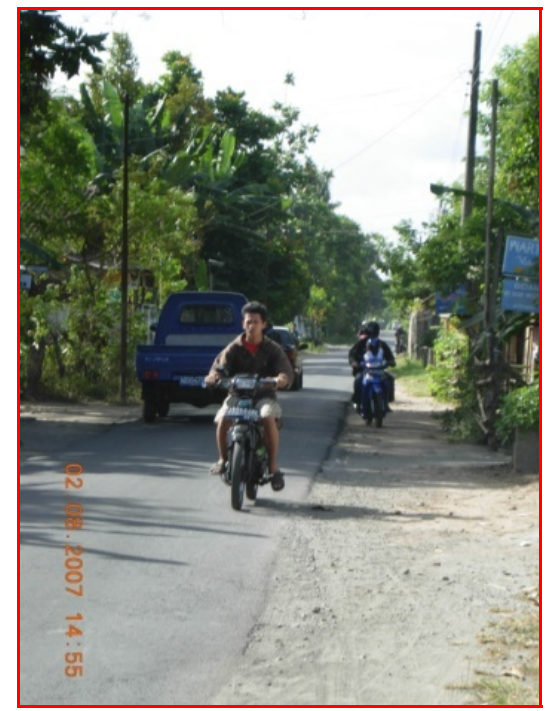

Gambar 14. Kepadatan lalulintas pada jalan utama

Jalur jalan yang ada menjadi alternatif menuju ring road selatan, maupun ringroad barat. Implikasinya, jalan cukup ramai terutama pada waktu sibuk (siang-sore) (Gambar 14). Selain kurang nyaman karena merupakan kawasan permukiman, dampak negatif yang ditimbulkan diantaranya adalah kebisingan dan polusi udara yang cenderung meningkat. Berdasarkan survey, masyarakat setempat merasa kondisi udara wilayah Nitiprayan sekarang lebih polutif dan menimbulkan kebisingan (74\%). Polusi ini tentunya mengganggu kesehatan bagi permukiman yang sangat dekat dengan jalan maupun warung-warung makan. Ditambah lagi dengan kondisi penghijauan yang masih kurang memadai jumlahnya. Kondisi ini akan terus mengancam, apalagi dengan potensi pengembangan kawasan.

\section{Konsep Pengembangan Wilayah}

Wilayah merupakan ruang pada permukaan bumi yang dapat dikelompokkan berdasarkan homogenitas karakteristiknya. Salah satu definisi dikemukakan Hartston (1982, dalam Hadi, 2001), dimana wilayah diartikan sebagai suatu area dengan lokasi spesifik dan dalam aspek tertentu berberda dengan area lainnya. Istilah ‘wilayah’ memiliki kesamaan dan sering dipertukarkan penggunaannya dengan 'daerah' dan 'kawasan'. Pada umumnya 'wilayah' menunjuk pada area/ruang secara umum, ‘daerah’ terkait dengan batasan administratif, dan 'kawasan’ untuk 
wilayah yang memiki kesamaan karakter (Tarigan, 2003). Dalam ketiga terminologi tersebut, suatu ruang atau area membutuhkan sebuah perlakuan atau upaya pengembangan untuk memenuhi kebutuhan manusia yang mengelolanya. Pada titik inilah, pembangunan sebagai upaya teknis dan politis memainkan peran utamanya.

Konsep manajemen memiliki idiom "gagal merencanakan sama dengan merencanakan gagal”, artinya perencanaan merupakan siklus pengelolaan yang sangat memegang peranan vital. Glasson (1974, dalam Sudjijono, 2004) mengungkapkan bahwa perencanaan menyangkut serangkaian tindakan yang ditujukan untuk memecahkan persoalan masa depan. Dalam bidang ekonomi regional dikenal dua teori utama (Sumodiningrat, 2000). Pertama, teori kutub pertumbuhan (growth pole theory), yang menjelaskan adanya konsentrasi pertumbuhan daerah di pusat (core), yang tidak selalu berdampak positif bagi daerah pinggiran (hinterland). Misalnya, kutub pertumbuhan di provinsi DIY adalah kota Jogja, yang selama 15 tahun terakhir cenderung berkembang ke utara khususnya ke wilayah kabupaten Sleman, dan sedikit ke wilayah kabupaten Bantul. Kedua, teori aglomerasi ekonomi, yang menjelaskan peranan urbanization economies dan localization economies. 'Penghematan urbanisasi' terjadi karena orang dan investor lebih suka memilih kawasan perkotaan, yang menawarkan penghematan biaya akibat kemudahan aksesibilitas dan keberadaan infrastruktur kota. 'Penghematan lokalisasi' muncul karena kedekatan geografis terhadap sumber bahan baku, tenaga kerja, dan knowledge spillover, menawarkan manfaat konsentrasi spasial.

Konsep ekonomi regional tepat untuk menjembatani kepentingan ekonomi dan kebutuhan spasial, sedangkan dalam konteks wilayah mikro konsep ekonomi kerakyatan lebih tepat sebagai pendekatan sektoralnya. Menurut Mubyarto (2002) Ekonomi Rakyat adalah kancah kegiatan ekonomi orang kecil (wong cilik), yang karena merupakan kegiatan keluarga, tidak merupakan usaha formal berbadan hukum, tidak secara resmi diakui sebagai sektor ekonomi yang berperanan penting dalam perekonomian nasional. Dalam terminologi tersebut terlihat perbedaan antara ekonomi kerakyatan (yang sekarang lebih lazim digunakan) dengan ekonomi rakyat. Ekonomi kerakyatan menunjuk pada sistem ekonomi (UU no. 25 Tahun 2000 tentang PROPENAS) ,sedangkan ekonomi rakyat adalah sektor riil berdasar pelakunya. Ekonomi rakyat merupakan sektor paling depan dalam perekonomian bangsa dan terbukti paling tinggi resistensi terhadap perubahan global, seperti krisis moneter. Untuk itu dalam pembangunan wilayah, pengembangan sektor ini perlu mendapat prioritas pemberdayaannya secara masif dan intensif. Pemberdayaan ekonomi rakyat menurut Mubyarto (2002) mengacu pada konsep yang pernah dikemukakan Sukarno (1930) dan Hatta (1931) dapat diimplementasikan melalui cara penghapusan sistem monopoli dan pemberdayaan dengan keberpihakan pemerintah. Konsep ekonomi rakyat juga 
berbeda dengan UKM dan sektor informal. Sektor UKM memiliki batas-batas kuantitatif dan sektor informal lebih menunjuk pada ketidakaturan suatu usaha karena tidak tunduk pada hukum. Sedangkan ekonomi rakyat jauh lebih luas menyentuh sisi perseorangan dan merupakan potensi yang sulit didekati dengan aspek hukum (Widodo et al, 2009).

Pengembangan wilayah utamanya adalah pengembangan masyarakat. Pengembangan masyarakat (community development) adalah suatu upaya perubahan terencana (planned change) yang dilakukan secara sadar dan sungguh-sungguh melalui usaha bersama masyarakat untuk memperbaiki keragaan sistem kemasyarakatan (Ginsberg, 2003). Arah perubahan akan sesuai dengan kesepakatan yang telah dirumuskan bersama. Menurut Widodo (2008), pada intinya instrument yang digunakan dalam community development adalah pemberdayaan (empowerment). Dengan partisipasi yang tinggi terhadap pembangunan, diharapkan rasa ikut memiliki dari masyarakat atas semua sumber daya yang bersifat open acces dan common property di lingkungan juga tinggi. Pendekatan ini perlu ditempuh karena masyarakat lokal adalah orang-orang yang paling tahu kondisi sosial budaya setempat. Setiap kegiatan pembangunan harus memperhatikan nilai-nilai sosial budaya pembangunan. Oleh karena itu, setiap langkah keputusan perencanaan harus mencerminkan keaktifan masyarakat lokal yang ikut terlibat di dalamnya. Dengan pelibatan masyarakat sejak awal akan lebih menjamin kesesuaian program pengembangan dengan aspirasi masyarakat karena adanya rasa memiliki yang kuat. Konsep pendekatan ini dalam jangka panjang akan memungkinkan tingkat kontinuitas yang tinggi.

\section{Arahan dan Strategi Pengembangan}

Potensi unggulan Kampung Nitiprayan adalah seni budaya. Mendasarkan hal tersebut, maka arahan umum pengembangan Kawasan Nitiprayan sebagai Kampung Wisata Terpadu. Kegiatan pengembangan hendaknya juga berupaya mengembangkan masyarakat menjadi lebih baik dan lebih sejahtera. Proses perubahan sosial akan lebih efektif jika didorong oleh faktor dari dalam yang sering disebut sebagai immanent change, dimana perubahan dikarenakan oleh ditemukannya berbagai inovasi baru dalam masyarakat itu sendiri. Pengembangan tersebut dapat dilakukan dengan arahan:

a. Berorientasi pada peningkatan kesejahteraan mayarakat lokal, sehingga pengembangan sepenuhnya dilakukan dengan basis pemberdayaan (community based development)

b. Tetap melestarikan karakter desa (rural), baik fisikal maupun sosio-kultural.

c. Mengutamakan partisipasi dan penguatan nilai kearifan lokal dalam seluruh proses pengembangan. 
d. Mengarahkan seluruh potensi lokal untuk mendukung terwujudnya Kampung Wisata Terpadu, seperti seni budaya, ekonomi rakyat, keramahan lingkungan, panorama perdesaan, dan kelengkapan infrastruktur.

Arahan adalah idealita yang masih membutuhkan strategi untuk merealisasikannya. Berdasarkan arahan umum yang diformulasikan untuk menuju Kawasan Nitiprayan sebagai Kampung Wisata terpadu, dapat diformulasikan pula strategi-strategi umum merealisasikannya:

a. Memanfaatkan dan mengoptimalkan daya dukung internal

b. Membangun networking dan koordinasi antar stakehoders, mulai dari lokal hingga internasional.

c. Pengembangan berbasis pemberdayaan menuju pengelolaan yang mandiri dan profesional (community based development dan knowledge based society).

d. Strategi implementasi memprioritaskan partisipasi dan meminimalisasi potensi konflik.

e. Pengembangan dilakukan secara sistematis, kontinu, dan menggunakan skala prioritas.

f. Menggunakan media rembug warga untuk membangun solidaritas sosial dan partisipasi publik.

Perubahan melalui pengembangan Nitiprayan tentunya akan termasuk perubahan nilai-nilai budaya yang ada pada masyarakat di kawasan ini. Perubahan tersebut diharapkan tidak merusak karakter desa sebagai suatu komunitas kebersamaan diantara mereka. Nilai-nilai kebersamaan, saling tolong menolong, dan kehidupan agamis hendaknya diantisipasi agar tidak berubah menjadi individualistik yang sekuler. Hal tersebut dapat dilakukan dengan pengembangan wisata yang berbasis pada kebudayaan masyarakatnya. Wisata yang ramah terhadap budaya dan bernuansa keagamaan merupakan bentuk pengembangan wisata yang dapat melestarikan budaya setempat.

Pengembangan Kawasan Nitiprayan dapat diorientasikan sebagai pusat pertumbuhan ekonomi yang berbasis seni budaya lokal, dengan konsep pengembangan desa wisata dengan karakter:

a) Kawasan Nitiprayan menjadi pusat kegiatan seni budaya yang berorientasi lokal dan mengolah produk seni dan industri kecil dan kerajinan pendukung menjadi bernilai ekonomi tinggi;

b) Kawasan Nitiprayan sebagai penyedia jasa pariwisata minat khusus dengan menampilkan seluruh kegiatan seni budaya yang ada;

c) Kawasan Nitiprayan sebagai pusat pertumbuhan harus dalam satu kesatuan sistem baik dari aspek manajemen, kreasi seni budaya, maupun pengembangan teknologi pendukung kegiatan seni budaya; 
d) Pengembangan ekonomi dilakukan dengan basis pemberdayaan ekonomi rakyat yang bernuansa lokal tapi berdaya saing global;

e) Perlunya menciptakan kekhasan produk lokal sebagai obyek daya tarik yang sifanya melengkapi, inovasi, atau menambah dari produk daerah lai;

f) Membatasi masuknya investor yang akan mengancam kemanfaatan bagi masyarakat lokal;

g) Pengembangan pola kemitraan dengan stakeholder lain yang berkompeten, seperti lembaga keuangan, pemerintah, dan lainnya.

h) Menggunakan sepenuhnya lembaga induk lokal dalam segala usaha pengembangan dan memberdayakan lembaga/komunitas di bawahnya;

i) Mengoptimalkan rembug warga sebagai sarana permusyawaratan dalam berpartisipasi serta mencegah iklim kompetesi yang tidak sehat.

j) Memberikan apresiasi lebih pada implementasi aktivitas sosial yang berorintasi pada terlestarikannya kearifan lokal dan ikatan sosial.

Beberapa langkah strategis yang dapat dilakukan dalam pengembangan sosial budaya dan ekonomi Kawasan Nitiprayan sebagai Kampung Wisata Terpadu adalah :

1. Sosialisasi dan Diskusi

2. Pemberdayaan masyarakat lokal

3. Pola regenerasi

4. Filterisasi dan selektivitas pengembangan wisata

5. Pengembangan sistem perencanaan terintegrasi

6. Pengembangan dengan pendekatan persuasive, regulation, dan market mechanism.

Lingkungan merupakan aspek fisik yang turut menjadi pendukung bagi pengembangan kawasan (Widodo dan Noordianto, 2006). Lingkungan yang nyaman dan sehat merupakan tuntutan atas arahan pengembangan kawasan sebagai Kampung Wisata Terpadu. Untuk itu, Kawasan Nitiprayan perlu diarahkan sebagai Kampung Wisata Hijau. Selain sebagai obyek daya tarik, arahan ini juga merupakan upaya antisipatif terhadap dampak yang mungkin dapat ditimbulkan. Formulasi pengelolaan lingkungan sebagai arahan komprehensif dengan aspek lainnya dalam upaya pengembangan Kawasan Nitiprayan seperti ditunjukkan dalam Tabel 1. 
Tabel 1 Matrik Arahan Pengelolaan Lingkungan Kawasan Nitiprayan

\begin{tabular}{|c|c|c|c|}
\hline Jenis Dampak & Penyebab Dampak & $\begin{array}{c}\text { Cara/Teknik } \\
\text { Pengelolaan Sekarang }\end{array}$ & Arahan Pengelolaan \\
\hline $\begin{array}{l}\text { Pencemaran } \\
\text { airtanah oleh } \\
\text { feces dan urine }\end{array}$ & $\begin{array}{l}\text { Septic tank terlalu } \\
\text { dekat dengan sumur, } \\
\text { karena padatnya } \\
\text { permukiman }\end{array}$ & $\begin{array}{l}\text { limbah domestik dibuang } \\
\text { ke septic tank pada tiap } \\
\text { rumah dan tidak disertai } \\
\text { peresapan }\end{array}$ & $\begin{array}{l}\text { - Pembuatan septic tank komunal disertai } \\
\text { peresapannya }\end{array}$ \\
\hline $\begin{array}{l}\text { Penurunan } \\
\text { kuntitas } \\
\text { airtanah, } \\
\text { khususnya saat } \\
\text { kemarau }\end{array}$ & $\begin{array}{l}\text { Kepadatan } \\
\text { permukiman, } \\
\text { Tidak adanya upaya } \\
\text { peresapan air hujan }\end{array}$ & $\begin{array}{l}\text { Penghematan air saat } \\
\text { kemarau }\end{array}$ & $\begin{array}{l}\text { - Pembuatan sumur resapan air hujan tiap } \\
\text { rumah dan drainase jalan } \\
\text { - Gerakan hemat air }\end{array}$ \\
\hline $\begin{array}{l}\text { Pencemaran air } \\
\text { Sungai Widuri }\end{array}$ & $\begin{array}{l}\text { Pembuangan limbah } \\
\text { rumah tangga dan } \\
\text { sampah }\end{array}$ & Belum ada & $\begin{array}{l}\text { - Pembuatan sumur resapan untuk limbah } \\
\text { cair rumah tangga atau system komunal } \\
\text { - Pengelolaan sampah terpadu } \\
\text { - Koordinasi dengan daerah hulu } \\
\text { - Filtering sampah pada bagian hulu dan } \\
\text { hilir kawasan } \\
\end{array}$ \\
\hline \begin{tabular}{l|} 
Kekumuhan \\
kawasan dan \\
berkembangnya \\
vector penyakit
\end{tabular} & \begin{tabular}{|l|} 
Pembuangan sampah \\
sembarangan;kurang \\
terawatnya \\
lingkungan \\
permukiman
\end{tabular} & $\begin{array}{l}\text { Sampah belum ada } \\
\text { pemilahan, sebagain } \\
\text { sampah dibuang ke } \\
\text { pekarangan tanpa galian } \\
\text { atau sungai }\end{array}$ & $\begin{array}{l}\text { - Pemilahan sampah dari rumah tangga } \\
\text { - Bak sampah rumah tangga tertutup } \\
\text { - Pengelolaan sampah terpadu dan } \\
\text { produktif } \\
\text { - Penempatan bak sampah di pinggiir jalan } \\
\text { - Program bersih lingkungan rutin dan } \\
\text { Gerakan sadar lingkungan } \\
\text { - Tamanisasi rumah dan jalan } \\
\text { - Penataan kawasan sungai } \\
\end{array}$ \\
\hline \begin{tabular}{l|} 
Polusi udara dan \\
polusi suara
\end{tabular} & $\begin{array}{l}\text { Bunyi dan asap } \\
\text { knalpot kendaraan } \\
\text { bermotor } \\
\text { Bau kotoran ternak }\end{array}$ & Belum ada & $\begin{array}{l}\text { - Penghijauan di sepanjang tepi jalan } \\
\text { utama } \\
\text { - Membuat sound barier pada pagar depan } \\
\text { rumah dengan tanaman } \\
\text { - Pembuatan papan peringatan tentang } \\
\text { batas kecepatan maksimum kendaraan } \\
\text { - Zoning kandang ternak di luar area } \\
\text { permukiman/pada area lahan sawah }\end{array}$ \\
\hline $\begin{array}{l}\text { Terganggunya } \\
\text { kelancaran } \\
\text { pengguna jalan }\end{array}$ & \begin{tabular}{|l} 
Parkir liar di tepi \\
jalan, tidak adanya \\
trotoar, rusaknya \\
sebagian ruas jalan, \\
penerangan dimalam \\
hari
\end{tabular} & Belum ada /terbatas & $\begin{array}{l}\text { - Menyediakan kantor parkir yang } \\
\text { representatif } \\
\text { - Pembuatan rambu khusus } \\
\text { - Pembangunan trotoar pedestrian } \\
\text { - Perbaikan jalan } \\
\text { - Penambahan lampu penerangan jalan }\end{array}$ \\
\hline $\begin{array}{l}\text { Banjir lokal } \\
\text { pada ruas jalan }\end{array}$ & $\begin{array}{l}\text { Drainase kurang } \\
\text { optimal, tidak ada } \\
\text { konsep peresapan }\end{array}$ & Belum ada & $\begin{array}{l}\text { - Pembuatan drainase disepanjang jalan } \\
\text { utama dan pemeliharaan berkala } \\
\text { - Pembuatan sumur resapan pada sistem } \\
\text { drainase dan pemeliharaan berkala }\end{array}$ \\
\hline $\begin{array}{l}\text { Penurunan } \\
\text { kesuburan dan } \\
\text { degradasi tanah }\end{array}$ & $\begin{array}{l}\text { Penggunaan pupuk } \\
\text { dan pestisida kimia, } \\
\text { usaha bata merah }\end{array}$ & Belum ada & $\begin{array}{l}\text { - Penggunaan pupuk dan pestisida alami } \\
\text { /organik } \\
\text { - Alih usaha bata merah }\end{array}$ \\
\hline
\end{tabular}

Beberapa langkah strategis yang dapat dilakukan dalam penataan ruang Kawasan Nitiprayan sebagai Kampung Wisata Terpadu adalah: 
1. Penyamaan persepsi dan membangun kesadaran tentang penaatan ruang dan permukiman oleh masyarakat maupun antar stakeholder.

2. Rembug warga untuk mendapatkan kesepakatan pola implementasi dan bentuk tata ruang dan permukiman, baik zoning yang rapi, pengusahakan aspek artistik dan arsitektural rumah maupun sarana pendukungnya, serta penataan lingkungan yang asri dan sehat.

3. Re-komitmen dengan pihak pengembang perumahan yang ada untuk menyediakan fasilitas dan memparhatikan aspek lingkungan

4. Sinergisitas dengan strategi pengembangan aspek lain untuk menata ruang permukiman, seperti pengembangan lahan pertanian, penataan lingkungan permukiman, pengembangan infrastruktur dan lainnya.

Beberapa langkah strategis yang dapat dilakukan dalam pengelolaan lingkungan Kawasan Nitiprayan sebagai Kampung Wisata Terpadu adalah:

1. Membangun dengan gerakan sadar lingkungan

2. Pengelolaan dengan pendekatan ekonomi, artinya dengan model pengelolaan lingkungan yang produktif dan bernilai ekonomis.

3. Dilakukan bertahap, sistem stimulan, dan secara swadaya.

4. Perlu keteladanan dari tokoh atau komunitas yang telah sadar.

5. Perlu pilot project untuk meyakinkan warga.

\section{Daftar Pustaka}

Ginsberg, Morris. (2003). Keadilan dalam Masyarakat, Pondok Edukasi, Yogyakarta.

Hadi, Sudharto P. (2001). Dimensi Lingkungan dalam Perencanaan, Yogyakarta: GMU Press.

Mubyarto. (2002). Reformasi Agraria: Menuju Pertanian, Journal Ekonomi Rakyat. Year. I, No. 8, October 2002, PUSEP GMU, Yogyakarta.

Prinz, D. (1999). Policies, Strategies and Planning for Integrated Rural Water Management. In: Hamdy, A., Lacirignola, Tekinel, O., Yazar, A. (eds) Proceedings, Advanced Short Course on "Integrated Rural Water Management: Agricultural Water Demands", Adana, Turkey, 20 Sept. - 02 Oct. 1999.

Sudjijono, Budi. (2004). Ekonomi Berkeadilan Sosial: Manatap Masa Depan Indonesia, Gholden Trayon Press, Jakarta.

Sumodiningrat, Gunawan. (2000). Perencanaan Pembangunan Daerah, Perpod, Jakarta.

Tarigan, Robinson. (2003). Perencanaan Pembangunan Wilayah, Bumi Aksara, Jakarta. 
Widodo, B. (2008). Water Resources Management for Anticipating Global Climate Change, National Seminar Water Resources Management for Anticipating Global Climate Change UII, Department of Public Work, Yogyakarta, 08 August 2009.

Widodo, B., and Noordianto, M.H. (2006). Managing Merapi with Rainwater Harvesting, International Seminar of Volcanic International Gathering (VIG), University of National Development (UPN), Yogyakarta, 07-08 September.

Widodo, B., Ribut, L., dan Donan, W. (2009). Urban Kampung Improvement on Global Warming Mitigation Basis (A Case Study of Code River Bank Settlement Area, Yogyakarta), Proceedings of The First International Seminar on Sicience and Technology, Islamic University of Indonesia (UII) - Universiti Kebangsaan Malaysia - Universiti Malaysia Trengganu, Januari 2009. 